\title{
Employee Commitment to Organizational Change with the Role of Job Satisfaction and Transformational Leadership
}

\author{
Nguyen Thi Bich Thuy \\ Lac Hong University (Faculty of Administration-International Economics), Vietnam \\ thuyntb@1hu.edu.vn \\ Phan Dang Ngoc Yen Van \\ Lac Hong University (Faculty of Administration-International Economics), Vietnam \\ vanpdny@,lhu.edu.vn
}

\begin{abstract}
This study aimed to analyze the role of job satisfaction and transformation leadership for employees' commitment to organizational change. Based on a survey sample of 381 employees in post-merger enterprises in retail and pharmaceutical sector and a linear regression model. The results revealed that Transformational leadership was associated positively and significantly with Affective Commitment $(\beta=.42, \mathrm{p}<.000)$, Normative Commitment $(\beta=.32$, $\mathrm{p}<.000)$, and Continuance Commitment $(\beta=.27, \mathrm{p}<.000)$; Job satisfaction was associated positively and significantly with Affective Commitment $(\beta=.24, \mathrm{p}<.000)$ and Normative Commitment $(\beta=.30, \mathrm{p}<.000)$ among employees' to organizational change. The results of this study provide a foundation of theory and practice for organizational changes that can efficiently exploit the human resource for the development in the next period.
\end{abstract}

Keywords. job satisfaction, organizational commitment, organizational change, transformational leadership, Vietnam

\section{Introduction}

Commitment is arguably one of the most critical factors involved in employees' support for change initiatives (Herscovitch \& Meyer, 2002). In the context of vibrant economic development in Vietnam, where competition is taking place so fiercely that the result may be the acquisition of large businesses for smaller businesses that often take place (Hosseini, Thu, \& Trang, 2017; Vuong, Napier, 
\& Samson, 2014). Mergers and acquisitions (M\&As) have been a very popular strategic maneuver for global businesses, attaining growth, diversification, or profitability (Schweizer, 2005). While there are positive outcomes associated with M\&A activity, such as growth and development, some of their disappointing results are associated with the mismanagement of the human side of it (Cartwright \& Schoenberg, 2007). Organizational change, such as merger and acquisition (M\&A) activity, continue to occur at a high rate in organizations (Herold, Fedor, Caldwell, \& Liu, 2008). Even though $70 \%$ to $90 \%$ of these mergers and acquisitions fail, organizations continue to look for opportunities to merge (Cartwright, Tytherleigh, \& Robertson, 2007; Pike, 2017; Raukko, 2009). There is undoubtedly a range of contributing explanations of these high M\&As failure rates; however, recently there has been growing acceptance among management researchers that the neglect and mismanagement of the human aspects during and following the actual merger or acquisition are significant determinants of merger success or failure (Seo, Taylor, Hill, Zhang, Tesluk, \& Lorinkova, 2012; Van Knippenberg, Martin, \& Tyler, 2006). M\&As have come to be associated with outcomes such as lower morale and job dissatisfaction, acts of sabotage, increased labour turnover and absenteeism rates rather than increased profitability (Armstrong-Stassen, Cameron, Mantler, \& Horsburgh, 2001). There is a consensus that such change activities result in reduced organizational commitment among employees (Datta, Guthrie, Basuil \& Pandey, 2010). Therefore, lowered commitment of employees after periods of mergers and change is identified as one of the reasons as to why the intended long-term effects of organizational change does not succeed (Cascio \& Wynn, 2004; Van Dierendonck \& Jacobs, 2012). Previous findings have indicated the potential importance of assessing employees' psychological contracts during a merger, in order to reach both the desired organizational outcomes and employee job satisfaction (Bellou, 2007; Shield, Thorpe, \& Nelson, 2002).

Organizational commitment and its determinants have received considerable attention from scholars with many studies, and explanatory factors tested to predict the commitment behaviour of employees with organizations (Chua et al., 2014; Currivan, 1999; Enache, Sallán, Simo, \& Fernandez, 2013; Igbal, 2010; Firth, Mellor, Moore, \& Loquet, 2004; Irving, Coleman, \& Cooper, 1997; Kumasey, Delle, \& Ofei, 2014; Meyer \& Allen, 1991; Mowday, Steers \& Porter, 1979; Rutishauser \& Sender, 2019; Saha, 2016). In the case of M\&As enterprises, employees experienced several unmotivated feelings, attitudes, and commitment behaviour to the new system (Bellou, 2006; Bligh, 2005; Cartwright and Cooper, 1993). Human resource management plays an crucial role in M\&As process success, and correlate significantly with positive employee behaviours and employee wellbeing (Aklamanu, Degbey, \& Tarba, 2016; Amiot, Terry, \& Callan, 2007; Chung, Du, \& Choi, 2014; Vasilaki, Tarba, Ahammad, $\&$ Glaister, 2016). Leadership is vital in the context of acquisitions and advocated the elements of transformational leadership (Morosini, Shane, \& Singh 1998; Nguyen \& Kleiner, 2003). Cumming et al. (2010) suggested that transformational leadership should be adopted to improve employees' 
satisfaction, selection, work environment, and to avoid employee turnover. Leaders provide vision and inspiration to their followers and create a structure and culture that will enable and facilitate various positive behaviours needed for integrating two organizations. In which, transformational leadership will support for effective human resource management practices in maintaining the employee's commitment of M\&As process (Brătianu \& Anagnoste, 2011; Jiali Zhang et al., 2014; Nemanich \& Keller, 2007; Pike, 2017; Savović, 2017; Vasilaki et al., 2016). The factors affecting the commitment behaviour of employees in organizational change which will be different from the factors that govern this behaviour in general and need to have empirical researches done to identify, accreditation. However, very few researchers have investigated the commitment perceptions of the employees who feel the full impact of these restructurings in the Vietnamese context. This study aims to identify and analyze the effects of job satisfaction and transformational leadership on employee commitment to organizational change in Vietnamese firm's context.

\section{Review of literature}

According to Vietnamese Enterprise Law (2014), enterprise merger is one or several companies that can be merged into another company by transferring all legal assets, rights, obligations and benefits to the merged company, and at the same time stop the existence of the enterprise merged. Commitment is widely defined as the extent of an individual's loyalty and attachment to an organization, linked to the degree of effort an individual will exert to support the organization's goals. Meyer and Allen (1991) widely used three-component commitment model is based on earlier work by Mowday, Steers, and Porter (1979). Commitment is the degree of attachment to an organization (O'Reilly \& Chatman, 1986). It has three major components: (i) a strong belief in the organization and acceptance of the organization's goals, (ii) a willingness to exert considerable effort on behalf of the organization, and (iii) a desire to maintain organizational membership (Mowday, Steers, \& Porter,1979).

Organizational commitment, a psychological contract that influences whether or not to remain affiliated with an organization, has three primary psychological states: (i) affective commitment: an employee wants to stay in the organization because of emotional attachments, (ii) continuance commitment: an employee remains with an organization because he/she has little chance of finding a better job, and (iii) normative commitment: an employee feels personally or ethically responsible for remaining with an organization (Meyer \& Allen, 1991). Studies show that each of these forms of commitment is associated with labour turnover. They also suggest that a strong relationship exists between affective commitment and a range of desirable employee outcomes, including attendance, job performance, good health, low stress, and minimize conflicts between work and other activities. As affective commitment is driven by work experience, rather than through the recruitment and selection of employees, perceived organizational support by employees is essential in this process (Meyer, Stanley, Herscovitch, \& 
Topolnytsky, 2002). Therefore, this study adopted affective commitment in measurement of employee's commitment in post-merger enterprises.

In examining human factors in M\&As, researchers have employed psychological, social, and cultural perspectives (Chung, Du, \& Choi, 2014; Marmenout, 2010). The psychological perspective shows that employees affected by M\&As are frequently exposed to high levels of psychological distress, role ambiguity, and anxiety from uncertainty (Cooper, Cooper, Dewe, \& O'Driscoll, 2001). According to the social perspective, employees both in acquired and acquiring firms tend to classify people based on the origin of their firm's identity theory, so they experience difficulties in overcoming biases (Amiot, Terry, \& Callan, 2007). The cultural perspective maintains that combining two distinct organizations with different cultures often leads to a cultural clash or collision that undermines performance (Marmenout, 2010).

\section{Job Satisfaction and Organizational Commitment to Change}

Theories of Maslow (1943), and Herzberg \& Mausner (1959), both emphasized the importance of meeting the different workers' needs such as jobs, payments and promotions that affect their behaviour in the organization, satisfaction and commitment. Job satisfaction is the attitude, resulting from reviewing and summarizing the specific likes and dislikes combined with the employees' evaluation on the work in the organization. Employees with high levels of organizational commitment are more workoriented than other employees. They get more satisfaction from work and view their jobs as fulfilling more of their personal needs. As a result, they are willing to exert considerable effort on behalf of the organization (Van Scotter, 2000). The more satisfied the worker is with the job, the higher the commitment with the organization (Firth, Mellor, Moore, \& Loquet, 2004; Martin \& Roodt, 2008). Kyei-Poku and Miller (2013) provided evidence for the positive relationship between job satisfaction with a merger and the affective and normative components of organizational commitment among employees.

According to the investigation, carried out by Aydogdu and Asikgil (2011), on the employees working in the service and production industry, a significant relationship is discovered between affective commitment and internal and external job satisfaction. Similar to this finding, it is realized that there is also a significant relationship between normative commitment and external and internal job satisfaction. Whereas a negative relationship was found out between internal job satisfaction and normative commitment; contrary to the expected findings, they found out a significant and positive relationship between external job satisfaction and continuance commitment.

Eslami and Gharakhani (2012) indicated that factors of Job satisfaction (promotions, personal relationships, and favourable conditions of work) have positive and significant effects on three components of organizational commitments in firms of services. Dirani and Kuchinke (2011) 
investigated the relationship between job satisfaction and organizational commitment in the banking sector. Results of the research showed that satisfaction and commitment were significantly correlated and satisfaction was a good predictor of commitment. Malik, Nawab, Naeem, and Danish (2010) indicated that the satisfaction with work-itself, quality of supervision and pay satisfaction had significant favourable influence on organizational commitment of employees. Ahmad and Oranya (2010) aimed to examine the relationship between nurses' job satisfaction and organizational commitment in culturally and developmentally different societies. According to the results, there was a positive and significant correlation between job satisfaction and total organizational commitment. Markovits, Davis, and Dick (2010) found out that extrinsic satisfaction and intrinsic satisfaction were more strongly related to affective commitment and normative commitment for public sector employees than for private-sector ones. A study conducted by Tsai, Cheng and Chang (2010) showed that job satisfaction positively influenced organizational commitment on hospitality industry employees. Likewise, Silva (2006) investigated the relationship between job satisfaction and organizational commitment on hospitality employees. The results showed that significant positive relationship between job satisfaction and organizational commitment was found.

H1a: Perceived job satisfaction positively influences an employee's affective commitment to organizational change.

H1b: Perceived job satisfaction positively influences an employee's normative commitment to organizational change.

H1c: Perceived job satisfaction negatively influences an employee's continuance commitment to organizational change.

\section{Transformational Leadership and Organizational Commitment to Change}

The keys to successful integration process of enterprises are a hands-on leadership styles, a bias for action, involvement of the entire staff, continuous focus on customers, and most of all, open and honest communication with employees (Nguyen \& Kleiner, 2003). Leadership can play a significant role in the preparation and integration of mergers and acquisitions by helping organizational members achieve common goals and minimizing the adverse effects associated with culture, the size of the organization, diversity, conflict, change, role modelling, team building, communication, planning and preparation, corporate reputation, and demographics (Pike, 2017). Mergers can be a significant source of trauma for both employees and management and often result in lowered trust, commitment, satisfaction, and productivity, and increased absenteeism, turnover and attitude problem (Bligh \& Carsten, 2005). Kotter (1996) claims that change always demands strong leadership. Leadership style has a substantial impact on the satisfaction, commitment for both the merger and the merged party's employees, in which the adaptive factor of leadership style changes that strongly affected the satisfaction 
as well as the employees' commitment of the merged party. Joyce Covin, Kolenko, Sightler, and Tudor (1997) explores the relationship between leadership style and post-merger satisfaction, noting from the results that leadership style is significantly related to merger satisfaction for employees of both acquiring and acquired firms. Being able to integrate quickly with enterprises after the merger will help employees with great motivation to associate with enterprises and the role of leadership style characterized by relationships, context, and inspiration, support and management will help workers in the process of rapid integration with the post-merger organization, thereby helping them connect with the organization (Schweizer \& Patzelt, 2012). Purvanova, Bono, and Dzieweczynski (2006) explained that the transitional leadership style plays a crucial role in creating employee commitment to work. Lok and Crawford (2004), and Lo, Ramayah, and Min (2009) explained that positive behaviour of leaders to motivate employees and enhance their commitment. Erkutlu's (2008) findings support the suggestion in the literature that transformational leadership behaviours stimulate organizational commitment and job satisfaction. Transformational leadership has a significant effect on job satisfaction, notably when employees demonstrated openness to change (Atmojo, 2015; Hinduan, Wilson-Evered, Moss, \& Scannell, 2009; Yang \& Islam, 2012). Nemanich and Keller (2007) investigated the influence of transformational leadership on the acceptance of acquisitions, employees' satisfaction, and employees' performance. Joyce Covin, Kolenko, Sightler, and Tudor (1997) explores the relationship between leadership style and post-merger satisfaction, noting from the results that leadership style is significantly related to merger satisfaction for both acquiring and acquired firm employees.

H2a: Perceived transformational leadership positively influences an employee's affective commitment to organizational change.

$\mathrm{H} 2 \mathrm{~b}$ : Perceived transformational leadership positively influences an employee's normative commitment to organizational change.

H2c: Perceived transformational leadership positively influences an employee's continuance commitment to organizational change.

\section{Methodology}

\section{Sample and Data Collection}

Hair, Black, Babin, and Anderson (2010) indicated that the sample size must total at least 100 to use exploratory factor analysis. Bentler and Chou (1987) proposed that the ratio of sample size to the number of free parameters may be 5:1 for a rational theory, primarily when many latent variables exist. Due to resource constraints, this study used a sample of 381 observations that ensure reliability for statistical tests in the research model. Table 1 presents descriptive statistics of demographic characteristics. Questionnaires were administered to employees of the post-merger enterprises in retail 
and pharmaceutical sector in Ho Chi Minh City of Vietnam, based on the non-probability sampling method (with convenient technique). The surveyed subjects in this study are employees working at postmerger enterprises, excluding newly recruited employees after the merger. The survey was conducted by the self-administered method, and employees were encouraged to complete the survey during work time.

\section{Measures}

To measure organizational commitment to change, we used the 18 items Organizational Commitment Questionnaire modified from Herscovitch and Meyer's (2002) scale. The items were classified in terms of the three dimensions of affective commitment, normative commitment and continuance commitment to organizational change. Job satisfaction was measured using the Hackman and Oldham's (1974) scale. This scale consists of five-items scale. The transformational leadership style was measured by a 16-items scale that was modified from the multi-factor leadership questionnaires (Bass \& Avolio, 1994).

Table 1 Demographic Differences Among Respondents

\begin{tabular}{lcc}
\hline Demographic characteristics & Frequency & Percentage \\
\hline Gender & 150 & 39.4 \\
$\quad$ Male & 231 & 66.6 \\
$\quad$ Female & 101 & \\
\hline Age & 142 & 26.5 \\
$\quad<25$ years & 85 & 37.3 \\
25-34 years & 53 & 22.3 \\
35-44 years & & 13.9 \\
$\quad>45$ years & 221 & \\
\hline Education level & 160 & 58.0 \\
Bachelor or higher & & 42.0 \\
Otherwise & 122 & 32.0 \\
\hline Working experience & 167 & 43.8 \\
Less than three years & 50 & 13.1 \\
3-5 years & 42 & 11.1 \\
6-10 year & & \\
> ten year & & \\
\hline Management position in post-merger & & \\
\hline
\end{tabular}




\begin{tabular}{lcc} 
Higher & 71 & 18.6 \\
Otherwise & 310 & 81.4 \\
\hline Type of organizations & & \\
Retail service & 231 & 66.6 \\
Pharmaceutical sector & 150 & 39.4 \\
\hline
\end{tabular}

Participants responded on a 5-point Likert-type scale dictating the extent to which they agreed with each statement as it reflected their present work environment $(1=$ strongly disagree, $5=$ strongly agree). Cronbach's alphas were as follows: 0.842 for affective commitment; 0.788 for normative commitment; 0.856 for continuance commitment; 0.825 for job satisfaction; 0.882 for transformational leadership. The Cronbach's alpha is considered adequate in order to ensure the reliability of the internal consistency of a scale (Hair, Black, Babin, \& Anderson, 2010).

\section{Results}

Table 2 showed the correlation coefficients between the independent variables are generally, and the variance inflation factors do not exceed 0.5 suggesting that multicollinearity is unlikely to prove a significant problem (Hair, Black, Babin \& Anderson, 2010). All of the hypothesized correlations are significantly different from zero and have the anticipated sign. Table 2 reports means, standard deviations, correlations among variables in the research model.

Table 2 Descriptive Statistics and Inter-correlations among Variables

\begin{tabular}{lcccccc}
\hline & Mean & S. D & $(1)$ & $(2)$ & (3) & (4) \\
\hline Job Satisfaction (1) & 3.89 & 0.70 & & & & \\
\hline Transformational Leadership (2) & 3.86 & 0.52 & $0.40^{* * *}$ & & & \\
\hline Affective commitment (3) & 3.92 & 0.63 & $0.41^{* * *}$ & $0.42^{* * *}$ & & \\
\hline Normative commitment (4) & 3.91 & 0.63 & $0.44^{* * *}$ & $0.40^{* * *}$ & $0.34^{* * *}$ & \\
\hline Continuance commitment (5) & 4.05 & 0.71 & 0.21 & $0.19^{* * *}$ & $0.25^{* * *}$ & $0.14^{* * *}$ \\
\hline
\end{tabular}

Note: ** Correlation is significant at the 0.01 level (2-tailed).

The regression analysis was carried out to determine the efficacy level of the job satisfaction and transformational leadership on affective commitment, normative commitment, and continuance commitment to organizational change.

The relationship between employee commitment to organizational change and job satisfaction and transformational leadership were estimated using OLS, and the results are shown in Table 3. As predicted, job satisfaction and transformational leadership were positively and significantly correlated with affective commitment to change at the 0.01 level. The result supported H1a and 2a. Also, job 
satisfaction and transformational leadership were positively related to normative commitment. Namely, $\mathrm{H} 1 \mathrm{~b}$ and $\mathrm{H} 2 \mathrm{~b}$ were supported. Finally, transformational leadership was positively related to continuance commitment. Namely, H2c was supported. The causal relationship between job satisfaction and continuance commitment was not significant. This result did not support H1c.

Table 3 The Results of Regression Analyses

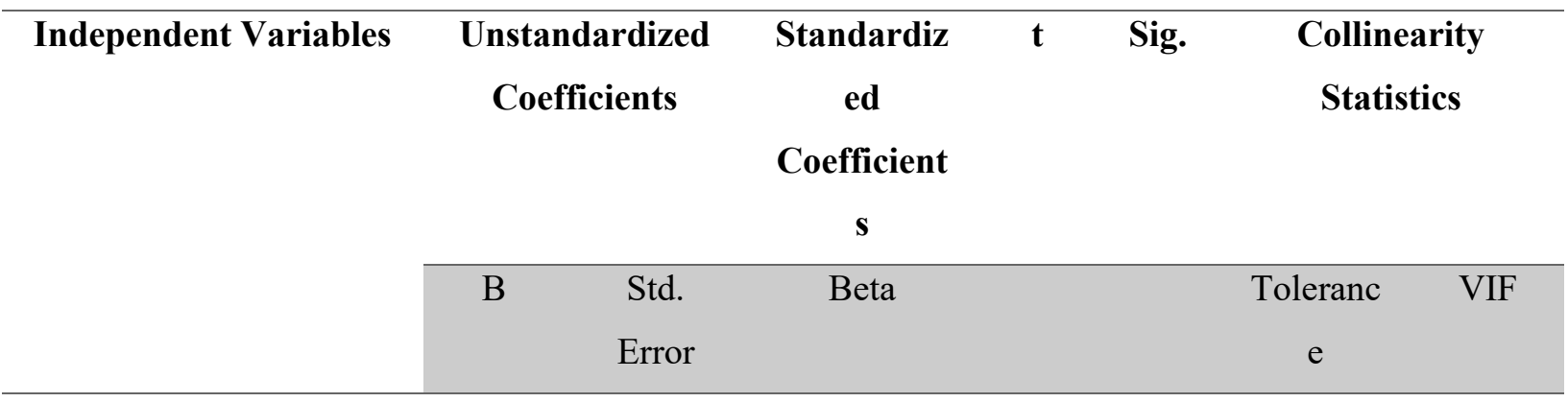

Dependent Variable: Affective Commitment to Change

\begin{tabular}{lccrrrrr}
\hline Constant & 1.37 & .22 & & 6.2 & .00 & \\
& & & 9 & 0 & \\
\hline Job Satisfaction & .24 & .04 & .27 & 5.5 & .00 & .84 & 1.19 \\
& & & 3 & 0 & & \\
\hline Transformational & .42 & .06 & .36 & 7.4 & .00 & .84 & 1.19 \\
Leadership & & & & 1 & 0 & & \\
\hline
\end{tabular}

$R^{2}=0.27 ;$ Adjusted $R^{2}=0.267 ; F=70.33 ;$ Durbin-Watson $=1.56$

\begin{tabular}{lccrrrrr}
\hline \multicolumn{7}{c}{ Dependent Variable: Normative commitment to Change } \\
\hline Constant & 1.52 & .22 & 6.7 & .00 & & \\
& & & 9 & 0 & & \\
\hline Job Satisfaction & .30 & .04 & .33 & 6.8 & .00 & .84 & 1.9 \\
& & & 6 & 0 & & \\
\hline Transformational & .32 & .06 & .26 & 5.4 & .00 & .84 & 1.9 \\
Leadership & & & 4 & 0 & & \\
\hline $\boldsymbol{R}^{2}=\mathbf{0 . 2 5}$; Adjusted $\boldsymbol{R}^{2}=\mathbf{0 . 2 4 7} ; \boldsymbol{F}=\mathbf{6 3 . 3 2}$; Durbin-Watson $=\mathbf{2 . 0 9}$ & & & \\
\hline
\end{tabular}

Dependent Variable: Continuance commitment to Change

\begin{tabular}{lrrrrrrr}
\hline Constant & 3.06 & .29 & & 10. & .00 & & \\
& & & & 74 & 0 & \\
& & & .06 & -.28 & .78 & .84 & 1.19 \\
\hline Job Satisfaction & -.02 & .06 & & & 3 & & \\
\hline
\end{tabular}




\begin{tabular}{lccrrrrr} 
Transformational & .27 & .08 & .08 & 3.6 & .00 & .84 & 1.19 \\
Leadership & & 3 & 0 & \\
\hline $\boldsymbol{R}^{2}=\mathbf{0 . 0 3 8 ;}$ Adjusted $\boldsymbol{R}^{2}=\mathbf{0 . 0 3 3 ;} \boldsymbol{F}=\mathbf{7 . 4 0}$; Durbin-Watson $=\mathbf{1 . 1 1}$ \\
\hline
\end{tabular}

Note: $p<0.05$; Independent Variable: Job Satisfaction and Transformational Leadership.

The results of regression analysis in Table 3 suggest that the $\mathrm{R}^{2}$ adjusted $(0.267)$ was significant at the 0,000 level for affective commitment. This means that $26.7 \%$ of the variance in affective commitment was significantly explained by job satisfaction $(\beta=.24 ; \mathrm{t}=5.53 ; \mathrm{p}=.000)$ and transformational leadership $(\beta=.42 ; \mathrm{t}=7.41 ; \mathrm{p}=.000)$. Namely, job satisfaction and transformational leadership were found to be a significant predictor of normative commitment to organizational change $\left(\mathrm{R}^{2}\right.$ Adjusted $=.247 ; \beta=.30$ and $.32 ; \mathrm{t}=6.86$ and 5.44 , respectively; $\left.\mathrm{p}=.000\right)$. This means that $24.7 \%$ of the variance in normative commitment were significantly explained by the job satisfaction and transformational leadership. Addition, transformational leadership was found to be a significant predictor of continuance commitment $\left(\mathrm{R}^{2}=.033 ; \beta=.27 ; \mathrm{t}=3.63 ; \mathrm{p}=.000\right)$. This means that $3.3 \%$ of the variance in continuance commitment was significantly explained by the transformational leadership.

\section{Discussion}

The findings of this study align with other research results (Pike, 2017; Yan, Wu, \& Zhang, 2016; Buiter \& Harris, 2013; Kyei-Poku, \& Miller, 2013; Calisir, Gumussoy, \& Iskin, 2011). This showed the relevance of the research model to the foundation of related theory and also indicated that human resource management activities in this field in the Vietnamese context and other environments are not different.

During the organizational change such as M\&As process, employees experience the merger syndrome, which is accompanied by increased self-interest, as employees become preoccupied with what the integration means for themselves, their incomes, and their careers. Employees seem to go through the merger as a loss of a loved one, often treated as a personal crisis, which may manifest itself as listlessness, apathy, a preoccupation with the past, lack of commitment to the new culture, fear, and active resistance to the new system (Cartwright \& Cooper, 1993). As a result, several negative attitudes and behaviours are realized, including decreased job satisfaction, organizational commitment, loyalty and productivity and increased defective products, mistakes and withdrawal behaviours (Bellou, 2006).

Human resource management plays an essential role in merger and acquisition integration success, emphasizing communication, employee involvement, teamwork and training and development and correlate significantly with positive employee behaviours and employee wellbeing (Aklamanu, Degbey, \& Tarba, 2016; Vasilaki, Tarba, Ahammad, \& Glaister, 2016). Employee participation and 
information sharing during M\&As increase self-efficacy and reduce the level of uncertainty and dysfunctional outcomes among employees (Chung, Du, \& Choi, 2014; Amiot, Terry, \& Callan, 2007).

Vasilaki, Tarba, Ahammad, and Glaister (2016) argued that communication, employee involvement, teamwork, and training and development have a positive effect on employee behaviour and their commitment with the newly formed organization. Training programs that offer employees appropriate information on M\&A, new organizational culture, and task-related skills and knowledge can reduce adverse reactions and enhance self-efficacy, resulting in improved post-change task performance. Training programs also elicit employee participation by promoting communication and information sharing related to the change among employees as well as by offering opportunities for them to voice their input to specific changes (Chung, Du, \& Choi, 2014; Brătianu \& Anagnoste, 2011). Job insecurity may lead to increased stress, anxiety, and turnover intentions among employees (Staufenbiel \& Konig, 2010). Thus, ensuring job security is an effective change management practice in reducing employee uneasiness and distress caused by M\&As as well as in maintaining and further enhancing task performance (Chung, Du, \& Choi, 2014; Stanwick \& Stanwick, 2001).

Human resource practices cannot be fully implemented if they are not monitored and controlled, and if employees are not coached to adapt to the new entity and not able to express their opinions, suggestions, and feelings about the challenges that may arise through the post-acquisition integration. Therefore, transformational leadership behaviours will moderate the implementation of human resource management practices in M\&As, leading to positive employee behaviour and employee identification in the new organization (Vasilaki, Tarba, Ahammad, \& Glaister, 2016; Jiali Zhang et al., 2014).

\section{Conclusion}

This study was carried out in the context of organizational change such as the M\&A market in Vietnam, is taking place very excitingly as a result of the business's strategy of enterprises as well as the consequence of competition becoming more and more so fierce. The merged enterprises in addition to the advantages, market opportunities, technology, finance and competitiveness acquired through merger deals, which also faced challenges due to the interests and cultural conflicts between the merged enterprises and the enterprises being merged, between members of merging organizations. Therefore, it is imperative to identify the factors affecting the employees' commitment in the post-merging enterprises based on harmonizing conflicts occurring to ensure the enterprises' success after the merger period, towards the stages of sustainable development. This study used a sample of primary data surveyed from 381 employees in the post-merger retail and pharmaceutical businesses in Vietnam. The results revealed the effect of job satisfaction and transformational leadership on employees' commitment to organizational change. The results of this study provide a foundation of theory and practice for 
organizational changes that can efficiently exploit the human resource for the development in the next period.

This study has some limitations. Firstly, the research sample that was collected only in two groups with new validation, including retail and pharmaceutical industry, surveyed in Ho Chi Minh City of Vietnam. Secondly, this study did not test the difference in organizational commitment between the attached employees' group before and after newly being recruited in the post-merged enterprises or the difference between the sectors after the merger. Thirdly, this study did not examine the influence of other factors on each component of organizational commitment to organizational change basic of models such as structural equation model. Further studies can exploit this topic as the research directions above.

\section{References}

[1] Ahmad, N., \& Oranye, N. O. (2010). Empowerment, job satisfaction and organizational commitment: a comparative analysis of nurses working in Malaysia and England. Journal of nursing management, 18(5), 582-591.

[2] Aklamanu, A., Degbey, W. Y., \& Tarba, S. Y. (2016). The role of HRM and social capital configuration for knowledge sharing in post-M\&A integration: a framework for future empirical investigation. The International Journal of Human Resource Management, 27(22), 2790-2822.

[3] Amiot, C. E., Terry, D. J., \& Callan, V. J. (2007). Status, equity and social identification during an intergroup merger: A longitudinal study. British Journal of Social Psychology, 46(3), 557577.

[4] Anderson, J. C., \& Gerbing, D. W. (1988). Structural equation modelling in practice: A review and recommended two-step approach. Psychological Bulletin, 103(3), 411-423.

[5] Armstrong-Stassen, M., Cameron, S. J., Mantler, J., \& Horsburgh, M. E. (2001). The impact of hospital amalgamation on the job attitudes of nurses. Canadian Journal of Administrative Sciences, 18(3), 149-162.

[6] Atmojo, M. (2015). The influence of transformational leadership on job satisfaction, organizational commitment, and employee performance. International Research Journal of Business Studies, 5(2), 113-128.

[7] Aydogdu, S \& Asikgil, B (2011). An empirical study of the relationship among job satisfaction, organizational commitment and turnover intention. International Review of Management and Marketing, 1(3), 43-53.

[8] Bass, B. M., \& Avolio, B. J. (1994). Transformational leadership and organizational culture. The International Journal of Public Administration, 17(3), 541-554.

[9] Bellou, V. (2006). Psychological Contract Assessment After A Major Organizational Change: The Case of After Mergers and Acquisitions. Employee Relations, 29(1), 68-88. 
[10] Bentler, P. M., \& Chou, C.-P. (1987). Practical issues in structural modelling. Sociological Methods \& Research, 16(1), 78-117.

[11] Bligh, M. C., \& Carsten, M. K. (2005). Post-merger psychological contracts: exploring a "multiple foci" conceptualization. Employee relations, 27(5), 495-510.

[12] Brătianu, C., \& Anagnoste, S. (2011). The role of transformational leadership in mergers and acquisitions in emergent economies. Management \& Marketing, 6(2), 319-326.

[13] Buiter, J. E., \& Harris, C. M. (2013). Post-merger influences of human resource practices and organizational leadership on employee perceptions and extra-role behaviors. SAM Advanced Management Journal, 78(4), 14-22.

[14] Calisir, F., Gumussoy, C., \& Iskin, I. (2011). Factors affecting intention to quit among IT professionals in Turkey. Personnel Review, 40(4), 514-533.

[15] Cartwright, S., Tytherleigh, M., \& Robertson, S. (2007). Are mergers always stressful? Some evidence from the higher education sector. European Journal of Work and Organizational Psychology, 16(4), 456-478.

[16] Cartwright, S., \& Cooper, C. L. (1993). The role of culture compatibility in successful organizational marriage. Academy of Management Executive, 7(2), 57-70.

[17] Cascio, W. F., \& Wynn, P. (2004). Managing a downsizing process. Human Resource Management, 43(4), 425-436.

[18] Chua, G. N., Yee, L. J., Sim, B. A., Tan, K. H., Sin, N. K., Hassali, M. A., Shafie, A. A., \& Ooi, G. S. (2014). Job satisfaction, organisation commitment and retention in the public workforce: a survey among pharmacists in Malaysia. International Journal of Pharmacy Practice, 22(4), 265-274.

[19] Chung, G. H., Du, J., \& Choi, J. N. (2014). How do employees adapt to organizational change driven by cross-border M\&As? A case in China. Journal of World Business, 49(1), 78-86.

[20] Cooper, C. L., Cooper, C. P., Dewe, P. J., \& O'Driscoll, M. P. (2001). Organizational stress: A review and critique of theory, research, and applications. Sage.

[21] Cummings, G. G., Macgeregor, T., Davey, M., Lee, H., Wong, C. A., Lo, E., Muise, M., \& Stafford, E. (2010), Leadership styles and outcome patterns for the nursing workforce and work environment: A systematic review, International Journal of Nursing Studies, 47, 363-385

[22] Currivan, D. B. (1999). The causal order of job satisfaction and organisational commitment in models of employee turnover. Human Resource Management Review, 9(4), 495-524.

[23] Datta, D. K., Guthrie, J. P., Basuil, D., \& Pandey, A. (2010). Causes and effects of employee downsizing: A review and synthesis. Journal of Management, 36(1), 281-348.

[24] Dirani, KM \& Kuchinke KP (2011). Job satisfaction and organizational commitment: validating the Arabic satisfaction and commitment questionnaire (ASCQ), testing the 
correlations, and investigating the effects of demographic variables in the Lebanese banking sector. The International Journal of Human Resource Management, 22(5), 1180-1202.

[25] Enache, M., M. Sallán, J., Simo, P., \& Fernandez, V. (2013). Organisational commitment within a contemporary career context. International Journal of Manpower, 34(8), 880-898.

[26] Erkutlu, H. (2008). The impact of transformational leadership on organizational and leadership effectiveness: The Turkish case. Journal of Management Development, 27(7), 708-726.

[27] Eslami, J., \& Gharakhani, D. (2012). Organizational commitment and job satisfaction. ARPN Journal of science and technology, 2(2), 85-91.

[28] Firth, L., Mellor, D. J., Moore, K. A., \& Loquet, C. (2004). How can managers reduce employee intention to quit?. Journal of managerial psychology, 19(2), 170-187.

[29] Hackman, J. R., Oldham, G. R. (1974), The Job Diagnostic Survey: An instrument for the diagnosis of jobs and the evaluation of job redesign projects.

[30] Hair, J. F., Black, W. C., Babin, B. J., \& Anderson, R. E. (2010). Multivariate Data Analysis: A Global Perspective (7th ed). Upper Saddle River, NJ: Pearson Education.

[31] Herold, D. M., Fedor, D. B., Caldwell, S., \& Liu, Y. (2008). The effects of transformational and change leadership on employees' commitment to a change: A multilevel study. Journal of applied psychology, 93(2), 346-357.

[32] Herscovitch, L., \& Meyer, J. P. (2002). Commitment to organizational change: Extension of a three-component model. Journal of applied psychology, 87(3), 474.

[33] Herzberg, F., Mausner, B., \& Snyderman, B. (1959). The motivation to work. New York: John Wiley and Sons.

[34] Hosseini, J. C., Thu, N. K., \& Trang, N. T. T. (2017). Vietnam Inbound M\&A Activity: The Role of Government Policy and Regulatory Environment. The South East Asian Journal of Management, 58-69.

[35] Hinduan, Z. R., Wilson-Evered, E., Moss, S., \& Scannell, E. (2009). Leadership, work outcomes and openness to change following an Indonesian bank merger. Asia Pacific Journal of Human Resources, 47(1), 59-78.

[36] Igbal, A. (2010). An Empirical Assessment of Demographic Factors, Organisational Ranks and Organisational Commitment. International Journal of Business and Management, 5, 16-27.

[37] Irving, P. G., Coleman, D. F., \& Cooper, C. L. (1997). Further assessments of a threecomponent model of occupational commitment: Generalizability and differences across occupations. Journal of Applied Psychology, 82(3), 444-452.

[38] Jiali Zhang, Mohammad Faisal Ahammad, Shlomo Tarba, Cary L. Cooper, Keith W. Glaister \& Jinmin Wang. (2014). The effect of leadership style on talent retention during Merger and 
Acquisition integration: evidence from China. The International Journal of Human Resource Management, (26)7, 1021-1050.

[39] Joyce Covin, T., Kolenko, T. A., Sightler, K. W., \& Tudor, R. K. (1997). Leadership style and post-merger satisfaction. Journal of management development, 16(1), 22-33.

[40] Kotter, J.P. (1996). Leading Change. Harvard Business School Press, Boston, MA

[41] Kumasey, S.A., Delle, E. \& Ofei, B.S. (2014) Occupational Stress and Organisational Commitment: Does Sex and Managerial Status Matter? International Journal of Business and Social Research (IJBSR), 4, 173-182.

[42] Kyei-Poku, I. A., \& Miller, D. (2013). Impact of employee merger satisfaction on organizational commitment and turnover intentions: A study of a Canadian financial institution. International Journal of Management, 30(4), 205-223.

[43] Lo, M.-C., Ramayah, T., \& Min, H. W. (2009). Leadership styles and organizational commitment: A test in Malaysia manufacturing industry. African Journal of Marketing Management, 1(6), 133-139

[44] Lok, P., \& Crawford, J. (2004). The effect of organizational culture and leadership style on job satisfaction and organizational commitment: A cross-national comparison. Journal of management development, 23(4), 321-338.

[45] Markovits, Y, Davis, AJ, Fay, D \& Dick, RV. (2010). The link between job satisfaction and organizational commitment: Differences between public and private sector employees. International Public Management Journal, 13(2), 177-196.

[46] Marmenout, K. (2010). Employee sensemaking in mergers: How deal characteristics shape employee attitudes. The Journal of Applied Behavioral Science, 46(3), 329-359.

[47] Martin, A., \& Roodt, G. (2008). Perceptions of organizational commitment, job satisfaction and turnover intentions in a post-merger South African tertiary institution. SA Journal of Industrial Psychology, 34(1), 23-31.

[48] Maslow, A. H. (1943). A theory of human motivation. Psychological Review, 50(4), 370-396.

[49] Meyer J P, Stanley D J, Herscovitch L., \& Topolnytsky L. (2002). Affective, Continuance and Normative Commitment to the Organization: A Meta-analysis of Antecedents, Correlates, and Consequences. Journal of Vocational Behavior, 61, 20-52.

[50] Meyer, J. P., \& Allen, N. J. (1991). A three-component conceptualization of organizational commitment. Human resource management review, 1(1), 61-89.

[51] Morosini, P., Shane, S., \& Singh, H. (1998). National cultural distance and cross-border acquisition performance. Journal of International Business Studies, 29,(1), 137-158.

[52] Mowday, R. T., Steers, R. M., \& Porter, L. W. (1979). The measurement of Organisational commitment. Journal of vocational behavior, 14(2), 224-247. 
[53] Nguyen, H., \& Kleiner, B. H. (2003). The effective management of mergers. Leadership \& Organization Development Journal, 24(8), 447-454.

[54] Nemanich, L. A., \& Keller, R. T. (2007). Transformational leadership in an acquisition: A field study of employees. The Leadership Quarterly, 18(1), 49-68.

[55] O'Reilly, C. A., \& Chatman, J. (1986). Organizational commitment and psychological attachment: The effects of compliance, identification, and internalization on prosocial behavior. Journal of applied psychology, 71(3), 492-499.

[56] Pike, B. (2017). Mergers: What ethical leaders can do to help ensure success. The Siegel Institute Journal of Applied Ethics, 4(1), 1-26.

[57] Purvanova, R. K., Bono, J. E., \& Dzieweczynski, J. (2006). Transformational leadership, job characteristics, and organizational citizenship performance. Human performance, 19(1), 1-22.

[58] Raukko, M. (2009). Organizational commitment during organizational changes: A longitudinal case study on acquired key employees. Baltic Journal of Management, 4(3), 331352.

[59] Rutishauser, L., \& Sender, A. (2019). Effect of Team-Member Exchange on Turnover Intention: A Cross-Cultural Perspective on a Selected Aspect of Employee Engagement. International Studies of Management \& Organisation, 1-20.

[60] Saha, R. (2016). Factors influencing organisational commitment-research and lessons. Management research and practice, 8(3), 36-48.

[61] Savović, S. (2017). The impact of dimensions of transformational leadership on the postacquisition performance of an acquired company. Ekonomski Horizonti, 19(2), 95-108.

[62] Schweizer, L., \& Patzelt, H. (2012). Employee commitment in the post-acquisition integration process: The effect of integration speed and leadership. Scandinavian journal of management, 28(4), 298-310.

[63] Schweizer, L. (2005). organizational integration of acquired biotechnology companies into pharmaceutical companies: The need for a hybrid approach. Acad. Managt. J., 48(6), 10511074.

[64] Seo, M. G., Taylor, M. S., Hill, N. S., Zhang, X., Tesluk, P. E., \& Lorinkova, N. M. (2012). The role of affect and leadership during organizational change. Personnel Psychology, 65(1), $121-165$

[65] Shield, R., Thorpe, R., \& Nelson, A. (2002). Hospital mergers and psychological contracts. Strategic Change, 11(7), 357-367.

[66] Stanwick, P. A., \& Stanwick, S. D. (2001). Human resources: Your secret weapon for postmerger success. Journal of Corporate Accounting \& Finance, 12(2), 9-14. 
[67] Staufenbiel, T., \& König, C. J. (2010). A model for the effects of job insecurity on performance, turnover intention, and absenteeism. Journal of Occupational and Organizational Psychology, 83(1), 101-117.

[68] Schweizer, L. (2005). Organizational integration of acquired biotechnology companies into pharmaceutical companies: The need for a hybrid approach. Acad. Managt. J., 48(6), 10511074.

[69] Silva, P. (2006). Effects of disposition on hospitality employee job satisfaction and commitment. International Journal of Contemporary Hospitality Management, 18(4), 317-328.

[70] Tsai, MC, Cheng, CC \& Chang, YY (2010). Drivers of hospitality industry employees' job satisfaction, organizational commitment and job performance. African Journal of Business Management, 4(18), 4118-4134.

[71] Van Dierendonck, D., \& Jacobs, G. (2012). Survivors and victims, a meta-analytical review of fairness and organizational commitment after downsizing. British Journal of Management, 23(1), 96-109.

[72] Van Knippenberg, B., Martin, L., \& Tyler, T. (2006). Process-orientation versus outcomeorientation during organizational change: the role of organizational identification. Journal of Organizational Behavior, 27(6), 685-704.

[73] Van Scotter, J. R. (2000). Relationships of task performance and contextual performance with turnover, job satisfaction, and affective commitment. Human resource management review, 10(1), 79-95.

[74] Vasilaki, A., Tarba, S., Ahammad, M. F., \& Glaister, A. J. (2016). The moderating role of transformational leadership on HR practices in M\&A integration. The International Journal of Human Resource Management, 27(20), 2488-2504.

[75] Vuong, Q. H., Napier, N. K., \& Samson, D. (2014). Relationship between innovations, capital expenditures and post-M\&A performance: evidence from Vietnam, 2005-2012. The IUP Journal of Business Strategy, 11(1), 34-41.

[76] Yan, S., Wu, S., \& Zhang, G. (2016). Impact of connective leadership on employees' goal commitment during M \& A integration. Leadership \& Organization Development Journal, 37(6), 789-801.

[77] Yang, Y. F. \& Islam, M. (2012). The influence of transformational leadership on job satisfaction: The balanced scorecard perspective. Journal of Accounting \& Organizational Change, 8(3), 386-402. 